\title{
Wind effects on trees
}

\author{
Dirk Schindler $\cdot$ Jürgen Bauhus $\cdot$ Helmut Mayer
}

Published online: 19 November 2011

(C) Springer-Verlag 2011

The interactions between airflow and trees and forest stands are diverse. They include the reduction in nearsurface wind speed and production of turbulence by trees. Near-surface wind conditions affect physiological processes in trees, tree growth, and survival (Ennos 1997; Eugster 2008). Turbulent components of the flow field dominate the tree response behaviour (Mayer 1987; Gardiner 1995; Schindler et al. 2010) and drive the scalar exchange at the forest-atmosphere interface (Finnigan 2000).

Wind-tree interactions take place at a wide range of temporal and spatial scales (de Langre 2008). Aerodynamic drag at all surfaces of the aerial parts of trees-from individual leaves (Vogel 1989) to whole tree crowns (Kane et al. 2008)—perturbs the airflow inside forest canopies (Shaw et al. 1974; Baldocchi and Meyers 1988; Turnipseed et al. 2003). Therefore, detailed information on forest structure is an essential precondition for understanding wind-tree interactions and the successful application of flow models to tall canopies. In flow models, forest structure is often represented by the mean vertical profile of the plant area density. Queck et al. (2011, this issue) present a method that can be used to record detailed 3D stand structure from terrestrial laser scanning. They investigated the relationship between wind speed, aerodynamic drag,

This article belongs to the special issue 'Wind Effects on Trees'.

D. Schindler $(\varangle) \cdot$ H. Mayer

Meteorological Institute, Faculty of Forest and Environmental

Sciences, Albert-Ludwigs-University, Freiburg, Germany

e-mail: dirk.schindler@meteo.uni-freiburg.de

\section{J. Bauhus}

Institute of Silviculture, Faculty of Forest and Environmental

Sciences, Albert-Ludwigs-University, Freiburg, Germany and plant area density and show how 3D laser scanner data can be used to derive turbulence parameters for flow models.

The structure of windward forest edges (Mitscherlich 1973; Dupont and Brunet 2008a, b) as well as the stand structure (Gardiner et al. 1997; Marcolla et al. 2003; Dupont and Brunet 2008b, c; Queck and Bernhofer 2010) affects the flow field within and above forests. In the nearedge region, pronounced gradients of flow quantities provoke high wind load on trees (Stacey et al. 1994; Peltola 1996; Gardiner et al. 1997), which may trigger damage in strong wind conditions. Although Gardiner and Stacey (1996) as well as Dupont and Brunet (2008a) report that tapered forest edges reduce wind loading and related bending moments of trees near the edge, it is still not completely clear, how changes in edge and stand structure affect the flow field at the canopy near forest edges, and whether these changes can contribute to the mitigation of damage in high wind conditions. In a detailed wind tunnel study, Ruck et al. (2011, this issue) investigated the effect of changes in taper angle of windward forest edges on the flow field for different stand densities. Their results demonstrate the impact of edge shape and stand density on quantities of the flow field near the canopy top, the region most relevant for tree failure in strong wind conditions.

The aerial parts of trees start to vibrate in response to wind excitation (Sellier and Fourcaud 2005; Rodriguez et al. 2008). In forests, dynamic tree responses are not only observed at the single tree level (Mayer 1987; Gardiner 1995; Peltola 1996; Flesch and Wilson 1999; Rudnicki et al. 2008; Schindler et al. 2010) but also at the tree group level (Rudnicki et al. 2001, 2003; Schindler et al. 2011, this issue). At both levels, the resulting tree response patterns are complex and complicated. So far, even in horizontally homogeneous terrain, not all physical and biological 
processes that govern wind-induced motion of forest trees are completely understood. Analyses of coherent responses of groups of trees to wind excitation (Schindler et al. 2011, this issue) contribute to a better understanding of spatial response pattern formation and dissipation of wind energy transferred into tree motion.

In strong wind conditions, wind excitation of trees may lead to damage. Branches, crowns, and stems can break, or trees can be thrown, when stem and root plate overturn (Quine and Gardiner 2007). Damage resulting from highimpact winds of large intensive depressions or from thunderstorm downburst may be catastrophic (Gardiner et al. 2008) and inflict substantial ecological, social, and economic impacts (Gardiner et al. 2010). Over the period 1950-2000, windstorms were responsible for 53\% of the total damage caused by natural disturbances in European forests (Schelhaas et al. 2003). However, while forest ecosystem disturbance through storms usually causes undesired impacts in forests managed for timber production, windstorms are also important and positive stimuli for changes in forest structure and composition as well as landscape patterns.

The factors influencing the probability of storm damage in forests may be divided into four groups, which are: (1) meteorological conditions, (2) site conditions, (3) topographic conditions, as well as (4) tree and stand characteristics (Mayer and Schindler 2002; Quine and Gardiner 2007). With respect to storm damage, site and topographic conditions can be characterised as quasi-static. Meteorological conditions as well as tree and stand characteristics show dynamic behaviour.

After the passage of high-impact windstorms, the resulting damage patterns are commonly analysed to reassess and, if required, to adapt current silvicultural concepts to mitigate future storm damage. Post-event analyses are often based on model-based investigations of wind-tree and root-soil interactions. Among the modelbased approaches, a large variety of statistical models can be distinguished from semi-mechanistic models like GALES (Gardiner et al. 2000), HWIND (Peltola et al. 1999), and FOREOLE (Ancelin et al. 2004). Although semi-mechanistic models require extensive sets of input parameters, they are well suited to identify and explore physical processes contributing to storm damage in forests. For this purpose, semi-mechanistic models calculate the critical wind speed, which is the wind speed above the forest canopy required to damage trees within a forest. Based on local wind climatology, the probability of a critical wind speed event can be determined (Gardiner et al. 2008). In their current versions, the semi-mechanistic models use the "mean" tree within uniform stands for predicting the probability of wind damage. The next generation of forest wind risk models will be able to calculate the wind risk to individual trees. Hale et al. (2011, this issue) demonstrate how the effects of tree size and thinning could be applied to future versions of semi-mechanistic models to assess storm damage risk to individual trees in forests with heterogeneous structures.

Semi-mechanistic models are also used to explore and simulate effects of root-soil interactions during strong wind events (Peltola et al. 1999; Gardiner et al. 2000, 2008; Nicoll et al. 2008). However, a better understanding of the interactions between rooting and soils is required to improve modelling of resistive forces of root systems. Besides the soil type, soil moisture is an important factor that controls resistive forces of the roots (Fraser 1962; Hütte 1967; Mayer 1987; Ray and Nicoll 1998; Gardiner et al. 2008; Peltola et al. 2010). Heavy rainfall associated with storm systems can raise soil moisture rapidly and hence also the predisposition of trees to windthrow (Usbeck et al. 2010). However, these effects have rarely been quantified. Here, the investigations of Kamimura et al. (2011, this issue) into the effects of rapid soil wetting on root anchorage will help to improve the description and parameterisation of root-soil interactions in semi-mechanistic models.

To assess the probability of storm damage in forests, statistical models are commonly used, although they provide only general insights into the physical mechanisms of storm damage and assume that future damage will occur under circumstances similar to those found for the analysed events. Among the published models are logistic regression models (Jalkanen and Mattila 2000; Mitchell et al. 2001; Hanewinkel 2005; Scott and Mitchell 2005; Schindler et al. 2009), neural networks (Hanewinkel et al. 2004; Hanewinkel 2005), classification and regression trees (Dobbertin 2002; Lindemann and Baker 2002), and generalised regression models (Schmidt et al. 2010; Albrecht et al. 2011 , this issue). The special feature of the model developed by Albrecht et al. (2011) is that it is based on a very large data set of individual trees from long-term growth and yield experiments, thus covering several storm events. The stepwise modelling approach used in this paper facilitated identification of the main risk factors for stand-level occurrence of storm damage, of total or partial stand damage, and for damage of individual trees within partially damaged stands. The analysis of data from forests in southwestern Germany showed that, in addition to tree species and stand height, previous silvicultural interventions were the most important predictors for storm damage.

In areas where recent silvicultural operations have decreased stand stability against wind loading, partial storm damage has many important, and not necessarily negative, implications for forests. In forested river ecosystems, one implication is that wind-thrown trees, which are deposited in a stream, contribute to island formation, 
physical complexity, as well as biocomplexity of a stream (Gurnell et al. 2005). For small streams bordered by forest, fallen trees can be the main source of large woody debris input from a riparian buffer (Lienkaemper and Swanson 1987). Since riparian buffers are particularly susceptible to partial storm damage after harvesting operations (Steinblums et al. 1984), the impact of partial wind damage in riparian buffers was analysed by Bahuguna et al. (2011, this issue). Their results show that wind-thrown trees are a potential source of sediment and that large woody debris adds to the structural complexity of small streams, where the former effect of windthrow is an undesirable and the latter a desirable outcome from a management perspective.

Although their location, frequency, or strength may change, severe windstorms will continue to occur all around the world. For example, Rauthe et al. (2010) reported that the current high level of storm activity will not drop considerably in future decades over southern and central Germany. Over northern Germany, the level of storm activity may even rise. As a consequence, more studies on the physical processes of storm damage and consistent further development of existing wind risk models should be valuable to adapt forest management systems on a site- and tree species-specific basis. But not only airflow characteristics of high-impact storms are important for the occurrence of future damage in forests. Gardiner et al. (2010) proposed that a higher air temperature in Europe during winter (Kjellström 2004) will result in longer periods of unfrozen soils, in which the root anchorage is reduced. This might promote wind damage particularly in northern European forests. Furthermore, winter precipitation intensity associated with storms might increase in decades to come (Palmer and Räisänen 2002). Heavier rainfall events involve more saturated soils and lead to an increase in storm damage probability (Usbeck et al. 2010). In combination with the ongoing build-up of growing stock in European forests, increased damage levels can be expected in the future (Schelhaas 2008; Hanewinkel et al. 2010).

Summarising the existing knowledge on wind-tree interactions at different scales, in particular wind-induced damage to forests and its reduction in the future, research should aim to improve our understanding of

- spatial (area of high-impact winds) and temporal (storm duration) scales of severe storms,

- interactions between high-impact winds and trees at the local and landscape level,

- interactions between high-impact winds and complex forest structures,

- small-scale variability of the soil-water balance and tree-soil interactions under rapidly changing meteorological conditions associated with high-impact storm events,
- impacts of climate change on regional risk of wind damage.

To address the knowledge gaps outlined above in the field of wind-tree interactions, the 2nd International Conference "Wind Effects on Trees" was held at the AlbertLudwigs-University of Freiburg (Germany), 13-16 October 2009. The conference brought together experts in theory, applications, and method development to present and discuss advances in this highly interdisciplinary field. Among the topics covered at the conference were (1) wind climatology, (2) airflow at forest edges, (3) air flow around trees, (4) aerodynamic interactions between wind and trees, (5) storm impacts and risk modelling, (6) mechanics of trees under wind loading, (7) failure criteria of trees, (8) ecological dynamics and strong wind conditions, (9) ecological dynamics following windthrow, (10) silviculture, tree level management, and harvest design to reduce wind damage, and (11) post-storm damage responses. Hence, the focus of the conference was on the behaviour of trees in high winds as well as the occurrence of storm damage and their impacts on forests (Mayer and Schindler 2009).

The papers that were selected to be presented in this special issue "Wind Effects on Trees" in the European Journal of Forest Research provide a good overview of the different issues discussed at the conference.

\section{References}

Albrecht A, Hanewinkel M, Bauhus J, Kohnle U (2011) How does silviculture affect storm damage in forests of south-western Germany? Results from empirical modeling based on long-term observations. Eur J For Res. doi:10.1007/s10342-010-0432-x

Ancelin P, Courbaud B, Fourcaud T (2004) Development of an individual tree-based mechanical model to predict wind damage within forest stands. For Ecol Manage 203:101-121

Bahuguna D, Mitchell SJ, Nishio GR (2011) Post-harvest windthrow and recruitment of large woody debris in riparian buffers on Vancouver Island. Eur J For Res. doi:10.1007/s10342-0110485-5

Baldocchi DD, Meyers TP (1988) Turbulence in a deciduous forest. Bound Layer Meteor 43:345-364

de Langre E (2008) Effects of wind on plants. Annu Rev Fluid Mech 40:141-168

Dobbertin M (2002) Influence of stand structure and site factors on wind damage comparing the storms Vivian and Lothar. For Snow Landsc Res 1(2):187-205

Dupont S, Brunet Y (2008a) Impact of forest edge shape on tree stability: a large-eddy simulation study. Forestry 81:299-315

Dupont S, Brunet Y (2008b) Edge flow and canopy structure: a largeeddy simulation study. Bound Layer Meteor 126:51-71

Dupont S, Brunet Y (2008c) Influence of foliar density profile on canopy flow: a large-eddy simulation study. Agric For Meteorol 148:976-990

Ennos AR (1997) Wind as an ecological factor. Trends Ecol Evol 12:108-111 
Eugster W (2008) Wind effects. In: Jörgensen SE, Fath BD (eds) Ecological processes, vol. 5 of Encyclopedia of Ecology. Elsevier, Oxford, pp 3794-3803

Finnigan J (2000) Turbulence in plant canopies. Annu Rev Fluid Mech 32:519-571

Flesch TK, Wilson JD (1999) Wind and remnant tree sway in forest cutblocks. II. Relating measured tree sway to wind statistics. Agric For Meteorol 93:243-258

Fraser AI (1962) The soil and roots as factors in tree stability. Forestry 35:117-127

Gardiner BA (1995) The interactions of wind and tree movement in forest canopies. In: Coutts MP, Grace J (eds) Wind and Trees. Cambridge University Press, Cambridge, pp 41-59

Gardiner B, Stacey G (1996) Designing forest edges to improve wind stability. Forestry commission technical paper no 16. Forestry Commission, Edinburgh

Gardiner BA, Stacey GR, Belcher RE, Wood CJ (1997) Field and wind tunnel assessment of the implications of respacing and thinning for tree stability. Forestry 70:235-252

Gardiner B, Peltola H, Kellomäki S (2000) Comparison of two models for predicting the critical wind speeds required to damage coniferous trees. Ecol Model 129:1-23

Gardiner B, Byrne K, Hale S, Kamimura K, Mitchell SJ, Peltola H, Ruel J-C (2008) A review of mechanistic modelling of wind damage risk to forests. Forestry 81:447-463

Gardiner B, Blennow K, Carnus J-M, Fleischer P, Ingemarson F, Landmann G, Lindner M, Marzano M, Nocoll B, Orazio C, Peyron J-L, Reviron M-P, Schelhaas M-J, Schuck A, Spielmann M, Usbeck T (2010) Destructive storms in European forests: past and forthcoming impacts. Final report to European Commission - DG Environment. http://www.efiatlantic.efi.int/files/attachments/efia tlantic/2010-storm/storms_final_report_main_text_141210b.pdf

Gurnell A, Tockner K, Edwards P, Petts G (2005) Effects of deposited wood on bio-complexity of river corridors. Front Ecol Environ 3:377-382

Hale SE, Gardiner BA, Wellpott A, Nicoll BC, Achim A (2011) Wind loading of trees: influence of tree size and competition. Eur J For Res. doi:10.1007/s10342-010-0448-2

Hanewinkel M (2005) Neural networks for assessing the risk of windthrow on the forest division level: a case study in southwest Germany. Eur J For Res 124:243-249

Hanewinkel M, Zhou W, Schill C (2004) A neural network approach to identify forest stands susceptible to wind damage. For Ecol Manage 196:227-243

Hanewinkel M, Hummel S, Albrecht A (2010) Assessing natural hazards in forestry for risk management: a review. Eur J For Res 130:329-351

Hütte P (1967) Die standörtlichen Voraussetzungen der Sturmschäden. Forstw Cbl 86:276-295

Jalkanen A, Mattila U (2000) Logistic regression model for wind and snow damage in northern Finland based on the National Forest Inventory data. For Ecol Manage 135:315-330

Kamimura K, Kitagawa K, Saito S, Mizunaga H (2011) Root anchorage of hinoki (Chamaecyparis obtuse (Sieb. Et Zucc.) Endl.) under the combined loading of wind and rapidly supplied water on soil: analyses based on tree-pulling experiments. Eur J For Res. doi:10.1007/s10342-011-0508-2

Kane B, Pavlis M, Harris JR, Seiler JR (2008) Crown reconfiguration and trunk stress in deciduous trees. Can J For Res 38:1275-1289

Kjellström E (2004) Recent and future signatures of climate change in Europe. Ambio 33:193-198

Lienkaemper GW, Swanson FJ (1987) Dynamics of large woody debris in streams in old growth Douglas-fir forests. Can J For Res 17:150-156
Lindemann JD, Baker WL (2002) Using GIS to analyse a severe forest blowdown in the Southern Rocky Mountains. Int J Geogr Info Sci 16:377-399

Marcolla B, Pitacco A, Cescatti A (2003) Canopy architecture and turbulence structure in a coniferous forest. Bound Layer Meteor 108:39-59

Mayer H (1987) Wind-induced tree sways. Trees 1:195-206

Mayer H, Schindler D (2002) Forstmeteorologische Grundlagen zur Auslösung von Sturmschäden im Wald im Zusammenhang mit dem Orkan "Lothar". Allg Forst Jgdztg 173:200-208

Mayer H, Schindler D (2009) In: Proceedings of the 2nd international conference on „Wind Effects on Trees“. Meteorological Institute, Albert-Ludwigs-University of Freiburg, Report no. 19

Mitchell SJ, Hailemariam T, Kulis Y (2001) Empirical modeling of cutblock edge windthrow risk on Vancouver Island, Canada, using stand level information. For Ecol Manage 154:117-130

Mitscherlich G (1973) Wald und Wind. Allg Forst Jagdztg 144:76-81

Nicoll BC, Gardiner BA, Peace AJ (2008) Improvements in anchorage provided by the acclimation of forest trees to wind stress. Forestry 81:389-398

Palmer TN, Räisänen J (2002) Quantifying the risk of extreme seasonal precipitation events in a changing climate. Nature 415:512-514

Peltola H (1996) Swaying of trees in response to wind and thinning in a stand of Scots pine. Bound Layer Meteor 77:285-304

Peltola H, Kellomäki S, Väisänen H, Ikonen V-P (1999) A mechanistic model for assessing the risk of wind and snow damage to single trees and stands of Scots pine, Norway spruce and birch. Can J For Res 29:647-661

Peltola H, Ikonen V-P, Gregow H, Strandman H, Kilpeläinen A, Venäläinen A, Kellomäki S (2010) Impacts of climate change on timber production and regional risks of wind-induced damage to forests in Finland. For Ecol Manage 260:833-845

Queck R, Bernhofer C (2010) Constructing wind profiles in forests from limited measurements of wind and vegetation structure. Agric For Meteorol 150:724-735

Queck R, Bienert A, Maas H-G, Harmansa S, Goldberg V, Bernhofer C (2011) Wind fields in heterogeneous conifer canopies: parameterisation of momentum absorption using high-resolution 3D vegetation scans. Eur J For Res. doi:10.1007/s10342011-0550-0

Quine CP, Gardiner BA (2007) Understanding how the interaction of wind and trees results in windthrow, stem breakage, and canopy gap formation. In: Johnson EA, Miyanishi K (eds) Plant disturbance ecology - the process and the response. Elsevier, Amsterdam, pp 103-155

Rauthe M, Kunz M, Kottmeier C (2010) Changes in wind gust extremes over Central Europe derived from a small ensemble of high resolution regional climate models. Meteorol Z 19:299-312

Ray D, Nicoll BC (1998) The effect of soil water-table depth on rootplate development and stability of Sitka spruce. Forestry 71:169-182

Rodriguez M, de Langre E, Moulia B (2008) A scaling law for the effects of architecture and allometry on tree vibration modes suggests a biological tuning to modal compartmentalization. Am J Bot 95:1523-1537

Ruck B, Frank C, Tischmacher M (2011) On the influence of windward edge structure and stand density on the flow characteristics at forest edges. Eur J For Res. doi:10.1007/s10342010-0451-7

Rudnicki M, Silins U, Lieffers VJ (2001) Measure of simultaneous tree sways and estimation of crown interactions among a group of trees. Trees 15:83-90

Rudnicki M, Lieffers VJ, Silins U (2003) Stand structure governs the crown collisions of lodgepole pine. Can J For Res 33:1238-1244 
Rudnicki M, Meyer TH, Lieffers VJ, Silins U, Webb VA (2008) The periodic motion of lodgepole pine trees as affected by collisions with neighbors. Trees 22:475-482

Schelhaas MJ (2008) Impacts of natural disturbances on the development of European forest resources: application of model approaches from tree and stand levels to large-scale scenarios. Dissertationes, forestales 56, Alterra scientific contributions 23

Schelhaas M-J, Nabuurs G-J, Schuck A (2003) Natural disturbances in the European forests in the 19th and 20th centuries. Global Change Biol 9:1620-1633

Schindler D, Grebhan K, Albrecht A, Schönborn J (2009) Modelling the wind damage probability in forests in Southwestern Germany for the 1999 winter storm 'Lothar'. Int J Biometeorol 53: $543-554$

Schindler D, Vogt R, Fugmann H, Rodriguez M, Schönborn J, Mayer $\mathrm{H}$ (2010) Vibration behavior of plantation-grown Scots pine trees in response to wind excitation. Agric For Meteorol 150: 984-993

Schindler D, Fugmann H, Schönborn J, Mayer H (2011) Coherent response of a group of plantation-grown Scots pine trees to wind loading. Eur J For Res. doi:10.1007/s10342-010-0474-0

Schmidt M, Hanewinkel M, Kändler G, Kublin E, Kohnle U (2010) An inventory-based approach for modelling single-tree storm damage - experiences with the winter storm of 1999 in southwestern Germany. Can J For Res 40:1636-1652
Scott RE, Mitchell SJ (2005) Empirical modelling of windthrow risk in partially harvested stands using tree, neighbourhood, and stand attributes. For Ecol Manage 218:193-209

Sellier D, Fourcaud T (2005) A mechanical analysis of the relationship between free oscillations of Pinus pinaster Ait. saplings and their aerial architecture. J Exp Bot 56:1563-1573

Shaw RH, Silversides RH, Thurtell GW (1974) Some observations of turbulence and turbulent transport within and above plant canopies. Bound Layer Meteor 5:429-449

Stacey GR, Belcher RE, Wood CJ, Gardiner BA (1994) Wind flows and forces in a model spruce forest. Bound Layer Meteor 69: 311-334

Steinblums IJ, Froehlich HA, Lyons JK (1984) Designing stable buffer strips for stream protection. J For 82:49-52

Turnipseed AA, Anderson DE, Blanken PD, Baugha WM, Monson RK (2003) Airflows and turbulent flux measurements in mountainous terrain Part 1. Canopy and local effects. Agric For Meteorol 119:1-21

Usbeck T, Wohlgemuth T, Dobbertin M, Pfister C, Bürgi A, Rebetez M (2010) Increasing storm damage to forests in Switzerland from 1858 to 2007. Agric For Meteorol 150:47-55

Vogel S (1989) Drag and reconfiguration of broad leaves in high winds. J Exp Bot 40:941-948 